no bearing on the subject of the high temperatures obtained by breathing through woven material on the bulb of a thermometer, for no one has yet observed that woollen clothing will develop a heat greater than that of the body it covers, viz., $98^{\circ} .5$.

The hygroscopic properties of different materials afford no explanation of the phenomena, for the power of materials to imbibe moisture will not account for an increase of their temperature by breathing through them.

My speculations may be right or wrong; Mr. McNally has not shown them to be either. My facts are not the less true from being incompatible with " ascertained physiological truths," for ascertained physiological truths are only true so long as they are not controverted by other ascertained physiological truths.

My experiments show that the temperature obtained by breathing on the thermometer in the manner described is higher when less caloric is abstracted from the surface of the body, lower when the surface of the body is losing more caloric. Thus on a warm summer day my breath raised the thermometer to $108^{\circ}$, whereas to-day (a cold wet day) it only raised the thermometer up to $103^{\circ}$. Does not this seem to show that respiration is a means of getting rid of the superfluous caloric generated in the body, and that when this excess of caloric cannot be got rid of by the skin it passes off by the breath? R. E. DUDGEON October 9

\section{Selenium}

As the only chance of being able to transmit images of reflection through a conducting wire, in the way sound is repeated to a distance by telephone, appears to lie in the preparation of a fairly transparent sheet of metallic selenium; it may tend to advance the subject if the difficulties experienced in dealing with this substance are mentioned.

Selenium in its vitreous condition melts about $220^{\circ}$ Fahrenheit, and can be drawn out between mica plates over a lamp, to a thin transparent red film. But heated for some time it turns black and granular, apparently absorbing hydrogen, then melts only at $423^{\circ} \mathrm{F}$., and is brittle and intractable. Unfortunately it is only in this crystalline state that its power of conducting electricity appears, and varies with the light under which the selenium is placed.

Prepared in the mass, electrically conducting selenium is as compact as the hardest gas carbon, with the shiny appearance and surface of graphite. How to reduce such a substance to any degree of transparency is perplexing. By reducing it to fine powder, and subjecting the black selenium to severe hydraulic pressure between hot polished steel plates, the desired effect might be produced. Selenium also dissolves freely in chloride of selenium, $\mathrm{Se}_{2} \mathrm{Cl}_{2}$, and precipitates slowly in a botyroidal mass of black selenium. It also separates in the crystalline form from concentrated solutions of selenide of potassium or sodium.

There is some uncertainty as to whether a transparent sheet could be more easily obtained by the method of precipitation, than by mere mechanical treatment. But the investigation is one that requires to be carried out with the aid of a fully equipped laboratory, and is beyond the power of an ordinary experimentalist.

To devise a successful mode of making a black substance like graphite at all translucent, requires a distinct understanding of the reason why bodies are opaque. Something more than an explanation in general terms is needed before camera pictures can be resolved into electric currents, and again integrated upon a receiving plate.

Perhaps some of the readers of NATURe may be able to suggest a method of dealing with selenium that will produce thin transparent sheets capable of conducting electricity.

London, October I6

A. T. F.

\section{Dynastes Hercules}

The reviewer of Ober's "Camps in the Caribbees" (NATURE, vol. xxii. p. 216) appears to doubt the story of the habits of the large Hercules beetle, Dynastes hercules, given by Ober on the authority of his guide. It is nevertheless perfectly true, and I have myself witnessed the occurrence twice in this neighbourhood, where the beetle is not uncommon. In the first instance I noticed it on a branch of Ochroma lagopus, and the second time on a species of Bombax, both very soft-wooded trees. The branches in each case were about thiee-quarters of an inch in diameter, half an inch being formed by the wood. In both cases $I$ saw the performance of the animal most distinctly, just as described by

Ober's guide, and I took not only a piece of the severed branch with me, but secured also the second animal. The noise is not so much produced by the cutting of the branch as by the open wings passing rapidly through the air during the rotation of the beetle. I do not believe there is anything of a sexual call in the manouvre. The beetle wants to get at the abundant juice of the young branches. It is called in this country aserrador, i.e. sazvyer. Golofa porteri, an allied insect of the same family as Lamellicornes, behaves in a similar way, but chooses of course thinner branches.

Carácas September 9

A. ERNST

\title{
What is Alrese?
}

In the large Encyclopédie published by Diderot and d'Alembert, vol. xii. p. 224 (edit. in folio) there is mentioned amongst the substances used for poisoning water to catch the fish, l'herbe qu'on appelle l'ALRESE. Littré has no such word, nor anything like it, nor indeed any other lexicographer I am able to consult here. I should be much obliged for any information on this name, or the plant referred to.

Carácas, September 9

\section{Rainfall of Sierra Leone}

As I believe there is little account taken of this climate at home, and as perhıps it might interest you, I send you an account of one day's rainfall this month, which is an excessive amount even for Freetown, and equal to one-third the whole year's rainfall for Dublin, I believe :-

$$
\begin{aligned}
& \text { Rainfall registered in the Colonial Hospital, Freetown, } 50 \text { feet } \\
& \text { above Sea-level } \\
& \text { From } 6 \text { a.m. to } 4 \text { p.m. September II } \ldots . . . \quad \begin{array}{ccc}
\text { Inches. } \\
6 * 35
\end{array} \\
& \text { From } 4 \text { p.m. to } 6 \text { a.m. September } 12 \text {... }
\end{aligned}
$$

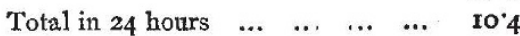

September 16

Colonial Surgeon

\section{An Octopus}

I INCLOSE an account of an enormous octopus which was thrown on the shore at Kilkee, Co. Clare, in the last great storm. As strangers find my uncle's hand very hard to read, I have copied his letter.

Ardanoir Foynes

\section{G. O'BRIEN}

"Saturday, October 9, 1880

"I am sorry you were not at Kilkee when a great octopus was stranded on the side of the Duggerna reef on Thursday last. Its arms had been partially broken : there were eight of them, each as thick as a strong man's upper arm, and beneath each were two rows of suckers like cupping-glasses, more than a shilling size in circuit. When perfect, each of these arms must have been from twelve to fifteen feet long, and from the point of one arm to that of its opposite was a length of nearly thirty feet. The animal's length from the insertion of its suckers to the end of its body must have been nearly twenty feet, perhaps more. Its mouth, like a parrot's beak, was as large as two joined hands of a large man with the fingers outstretched. It weighed about $4 \mathrm{cwt}$. Its head was $\mathrm{I} \frac{1}{2}$ inch in diameter, about three feet long; its eyes of the size of the inner circuit of a breakfast-plate. A monster. The under colour that of the under side of a turbot." -(From a letter of the Rev. R. J. GABBETT.)

\section{SYNTHESIS OF CITRIC ACID}

$\Lambda \mathrm{S}$ we intimated last week, another brilliant synthesis $A$ has recently been accomplished in the domain of organic chemistry. Messrs. Grimaux and Adam have succeeded in building up the characteristic acid of lemons from glycerin. Glycerin may be regarded as trihydroxypropane, $\mathrm{C}_{3} \mathrm{H}_{5}(\mathrm{OH})_{3}$, and citric acid as hydroxypropanetricarboxyllic acid, $\mathrm{C}_{3} \mathrm{H}_{4}(\mathrm{OH})\left(\mathrm{CO}_{2} \mathrm{H}\right)_{3}$. To convert glycerin into citric acid it was therefore necessary to replace two hydroxyl groups, and one hydrogen atom, by the group $\mathrm{CO}_{2} \mathrm{H}$ (carboxyl). This was done as follows:-By the action of hydrochloric acid on glycerin, dichlorhydrin, 


$$
\mathrm{CH}_{2} \mathrm{Cl}-\mathrm{CH}(\mathrm{OH})-\mathrm{CH}_{2} \mathrm{Cl}
$$

was produced; this was oxidised by potassium dichromate and sulphuric acid, to dichloracetone,

$$
\mathrm{CH}_{2} \mathrm{Cl}-\mathrm{CO}-\mathrm{CH}_{2} \mathrm{Cl} \text {, }
$$

which, when acted on by concentrated hydrocyanic acid, yielded dichloracetone cyanhydrin,

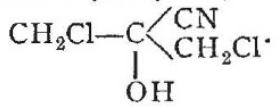

The acid corresponding to this cyanhydrin having been produced by saponifying with hydrochloric acid, the sodium salt of this acid, viz.,

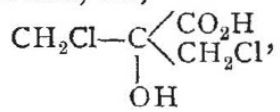

was treated with potassium cyanide, whereby a dicyanide,

$$
\begin{gathered}
\mathrm{CH}_{2} \mathrm{CN}-\underset{\mathrm{OH}}{\mathrm{C}}\left\langle\mathrm{CH}_{2} \mathrm{H}\right. \\
\mathrm{CH}_{2} \mathrm{CN} \\
\mathrm{CH}
\end{gathered}
$$

was produced. When decomposed by hydrochloric acid, this dicyanide yielded citric acid, in all respects identical with that obtained from the lemon and other fruits. The generally accepted structural formula for citric acid, viz.,

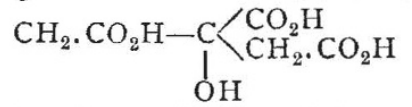

is confirmed by the synthesis of Grimaux and Adam. Glycerin may be prepared from trichlorhydrin,

$$
\mathrm{CH}_{2} \mathrm{Cl}-\mathrm{CHCl}-\mathrm{CH}_{2} \mathrm{Cl} \text {, }
$$

which is itself obtained by the action of chlorine in daylight on propylenic chloride,

$$
\mathrm{CH}_{3}-\mathrm{CHCl}-\mathrm{CH}_{2} \mathrm{Cl} \text {, }
$$

one of the products of the chlorination of propylene, $\mathrm{C}_{3} \mathrm{H}_{6}$. Finally this hydrocarbon, propylene, may be produced by passing a mixture of carbon monoxide and marsh gas through a red-hot tube. Inasmuch as carbon monoxide and marsh gas are easily built up from carbon, hydrogen, and oxygen, the synthesis of citric acid from these three elements is now an accomplished fact.

In connection with this synthesis, it is worthy of remark that in the last number of the Berlin Berichte, Kekule announces that he has been working at the same subject, but by a totally different method. Kekule's work is not sufficiently advanced for him to say positively that his method of synthesis is successful, but he feels justified in saying that very probably the process adopted by him has resulted in the formation of citric acid.

$$
\text { M. M. P. M. }
$$

\section{PLANTS FROM LAKE NYASSA AND LAKE TANGANYIKA}

$M^{R}$. THOMSON, who has recently returned from the $M$ expedition of the Royal Geographical Society to Central Africa, has brought to Kew a considerable collection of plants from the plateaux round Lake Nyassa and Lake Tanganyika. The plants from an elevation of 6,000 to 8,000 feet above sea-level contain a large proportion of Cape and characteristically temperate types. Amongst the former are the well-known Dierama (Sparaxis) pendula, Scilla rigidifolia, Buphane toxicaria (the great poison bulb of Natal and the Transvaal), a fine Morea with a long tube and bright purple flowers as large as those of Iris fatidissima, a Gladiolus, a Pelargonium, more than one species of Gnidia and Helichrysum, and a proteaceous shrub (probably Faurea, which extends to Abyssynia) with large heads of flowers. Of characteristically temperate types there are species of Geranium, Kumex, Cerastium, Coalamintha, and a Scabiosa, perhaps identical with our European and English $S$. Columbarice. Upon the plateaux below 6,000 feet the vegetation assumes a sub-tropical character. Here he met with a tree-fern of the genus Cyathea, 'A gauria salicifolia, Hook, fil, an ericaceous shrub common to Bourbon, Madagascar, and the Cameroons, representatives of Mimulopsis, Hibiscus, Clematis, Phyllanthus, Gerbera, Smithia, Acalypha, Pentas, Thunbergia, Buchnera, Striga, a shrubby Spermacoce, a curious Loranthus with broad leaves and tubular flowers densely clothed with yellow hairs, Hypoxis Villosa, several fine Dombeyas, Vernonias, and Combretums, a genus of Hedysarea with flowers in heads like those of the hop, and a curious broad-leaved Euphorbia, with very large hand-like glands to the involucre. The specimens are well selected and excellently dried. It is probable that nearly all of them are in a condition in which their botanical position can be settled, and that although upon a hasty glance there do not seem to be any strongly-marked new generic "types, a good many of the species will prove new to science. The marked northern extension of the Cape flora at comparatively high elevations in Central Africa is a fact of importance. It quite supports the theory that that flora is of great antiquity, and that what exists of it at the Cape is only a survival from a period when it was probably far more extensively diffused, though perhaps less highly specialised. It is much to be desired that travellers in Central Africa would do all in their power to collect dried specimens of the vegetation of elevations above 6,000 feet.

\section{GRAHAM BELL'S EXPERIMENTS IN BINAURAL AUDITION}

PROF. GRAHAM BELL has published in the American (quarterly) Journal of Otology a memoir on some experiments relating to binaural audition, read by him last autumn at the session of the American Association for the Advancement of Science. Some of his observations confirm the work of previous observers, but are of additional value in affording a more systematic examination of some of the phenomena than has hitherto been attempted. The following summary of the results obtained by him will therefore be of some interest.

When we close one ear and listen to sounds through the other only, there seems to be a onesidedness about them, as there is about objects perceived by one eye. When both ears are employed simultaneously a sort of stereoscopic effect of audition is perceived. Sounds assume a "solidity" which was not perceptible so long as one ear alone was employed. The difference between monaural and binaural audition is especially well marked when we attempt to decide by ear the locality of a particular sound. Whatever power a single ear may possess of determining the direction of a source of sound, both ears are certainly much more effective for this purpose.

The following experiment, designed to produce artificially the stereophonic phenomena of binaural audition, was therefore devised by Prof. Bell while in this country in 1878 . Four telephones were arranged, as in the figure. The telephones $A$ and $B$ in one room; C and D in another. The mouthpieces of $A$ and $B$ were turned away from one another like the auricles of a person's ears, and the diaphragms were about as far apart as the tympana of the two ears. The expectation was that a person holding $C$ and $D$ to his ears should not simply hear speech when any one was talking near $A$ and $B$, but that he should be able to perceive the direction of the speaker's voice relatively to $A$ and $B$. In fact, the listener's ears were, as it were, electrically prolonged to $\mathrm{A}$ and $\mathrm{B}$ respectively. The sensations produced were decidedly novel; but not exactly such as had been expected. Using various sources of sound-speaking, ringing a loud dinner-bell in various parts of the room, \&c.- it was found that the location of the sound could be determined to a limited extent. The 